\title{
Protein C deficiency
}

\author{
Arun K. De $\cdot$ Somnath Pal $\cdot$ Santanu Das $\cdot$ \\ Tunisa Bhattacharya
}

Received: 6 October 2012/ Accepted: 20 August 2013/Published online: 11 September 2013

(c) Indian Society of Haematology \& Transfusion Medicine 2013

\begin{abstract}
This report describes a 4 year old female child who presented with fever, pain and swelling of left leg following a trivial trauma. She was diagnosed as a case of deep vein thrombosis and subsequently found to be due to protein $\mathrm{C}$ deficiency.
\end{abstract}

Keywords Deep vein thrombosis - Protein C .

Antithrombin III · Protein S

\section{Introduction}

Beyond neonatal period, thrombotic events are rare in children. The estimated annual incidence of venous thrombotic events is about 0.5 per 10,000 newborns. The association between inherited thrombophilia and thrombosis varies depending on clinical scenario; children with unprovoked thrombosis have a high chance of inherited thrombotic defects, while catheter related thrombosis are rarely associated with inherited defects. Protein C defi-

\footnotetext{
A. K. De $\cdot$ S. Pal $\cdot$ S. Das $\cdot$ T. Bhattacharya

Department of Pediatric Medicine, Medical College, Kolkata, India

e-mail: somnathpal1983@gmail.com

S. Das

e-mail: doc.sanpaed@gmail.com

T. Bhattacharya

e-mail: atasikde@rediffmail.com

\section{A. K. De $(\bowtie)$}

Anandalok Co-operative Housing Society, Flat No. 2/1, BB-50,

Action Area: I B, New Town, Kolkata 700156, India

e-mail: arunkrde@rediffmail.com
}

ciency is a rare genetic abnormality that predisposes the patient to thrombophilia and leads to thrombosis, often at unusual sites [1]. We are presenting a case of deep vein thrombosis (DVT) of lower limb which was subsequently found due to protein $\mathrm{C}$ deficiency.

\section{Case Report}

A 4 year old, female child presented in the emergency with the complaints of progressive swelling and pain in the left lower limb for last 4 days following a trivial trauma 1 week back. It was associated with intermittent, low grade fever. Other leg was normal with no similar history in past or in any family members. Examination revealed edematous left leg with dilated veins and petechial spots (Fig. 1). Peripheral arterial pulses were normally palpable. Local temperature was raised. So, our initial clinical diagnosis was either DVT or cellulitis. We started the child on intravenous antibiotics, analgesics and antipyretics. Straight X-ray of left lower limb was normal. We noticed swelling and pain in the hand of the child distal to the site of intranous cannulation on the next day. Colour Doppler study of venous system of left lower limb revealed dilated left common iliac, external iliac, common femoral and superficial \& deep femoral veins with echogenic material within it. These veins are not compressible. Partial colour filling of lumen of lower $1 / 3$ rd of superficial femoral vein was noted. Rest of the above mentioned veins show no flow within it. Left popliteal vein lumen was free, compressible with normal colour filling. Inferior vena cava lumen was free. We made a diagnosis of DVT of left lower limb and we started exploring the causes of DVT. There was no history of prior intravenous cannulation, any chronic medical illness, chronic use of any medication, weight loss, 
immobilisation and surgery in the affected limb. Computerised tomographic (CT) scan of abdomen and pelvis revealed thrombosis of left illio-femoral venous system with no intra abdominal pathology or mass. Complete hemogram, chest $\mathrm{X}$ ray and echocardiography were normal. Platelet count was within normal range. Blood culture revealed no growth. There was no history of dyspnea, chest pain, cough or hematuria. ESR found to be raised $(52 \mathrm{~mm}$ in first hour). Baseline PT was 13.8/13.0 (INR-1.06) and a PTT was 29.5/35.0. Blood levels of anti phospholipid antibody, AT-III, protein S, homocysteine were normal. Activated protein $\mathrm{C}$ resistance was absent. Protein $\mathrm{C}$ level was significantly reduced (39.2\% of normal).

Child was started on low molecular weight heparin and after 7 days of treatment with LMWH, we gradually replaced it with acenocoumarol with the aim of maintaining INR at 1.5. Gradually limb oedema and calf pain subsided and dilated veins disappeared with no re-appearance of symptoms.

\section{Discussion}

Protein $\mathrm{C}$ is one of the natural anti-coagulants of the hemostatic system. Synthesized in liver, protein $\mathrm{C}$ is a vita$\min \mathrm{K}$ dependent protein. At the site of thrombinthrombomodulin complex formation, protein $\mathrm{C}$ gets converted into activated protein $\mathrm{C}$, which in the presence of cofactor protein $\mathrm{S}$, proteolyses and inactivates factor $\mathrm{Va}$ and VIIIa [2]. Familial transmission of protein C deficiency are possible with inheritance pattern either autosomal

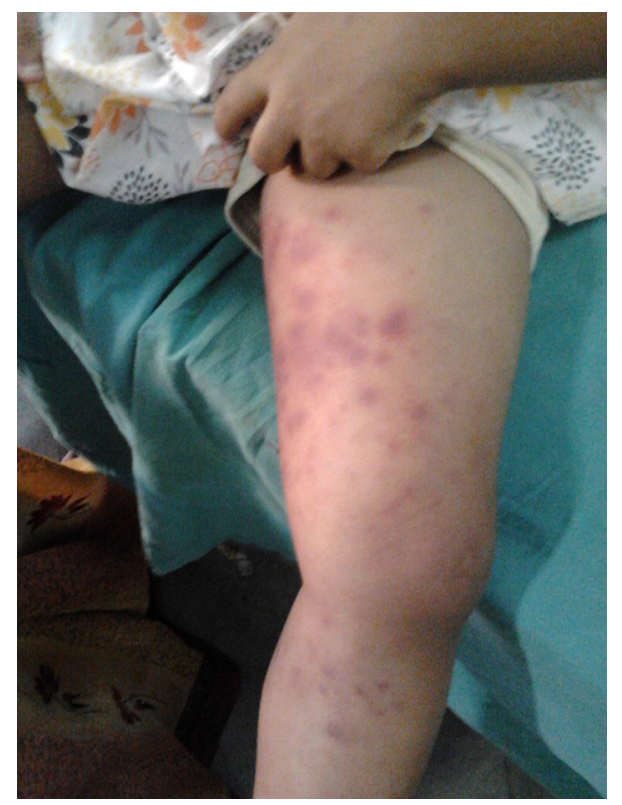

Fig. 1 Showing oedematous left leg with dilated veins and petechial spots dominant or autosomal recessive. Homozygous deficiency may present in neonatal period as purpura fulminans [3]. The population prevalence of heterozygous protein $\mathrm{C}$ deficiency is estimated at $0.2 \%$ and heterozygous deficiency of protein $\mathrm{C}$ is not a significant problem during the neonatal period. In heterozygotes with protein $\mathrm{C}$ level around $50 \%$ of normal are at risk of thrombo-embolic events following some precipitating factors like infection, trauma or central venous catheter (CVC) placement. Trauma is the precipitating factor in our patient. Acquired deficiency of protein $\mathrm{C}$ may be caused by liver disease, DIC, sepsis and drugs [4]. Compared to adults, the incidence of arterial and venous thrombosis in children is much less [5]. But in recent years, because of advancement in the treatment and supportive care of critically ill child along with increased awareness about risk factors for thrombosis, we are diagnosing it at increased frequency. But still thrombo-embolism is rare in children. Infants account for the majority of the cases, with a second peak occurring at the adolescent period. Other risk factors are placement of a central venous catheter, infection, trauma, medications (Lasparaginase, OCP), chronic medical illness (nephrotic syndrome, malignancy), pregnancy, immobilisation and hereditary factors [4]. Among hereditary factors, factor $\mathrm{V}$ Leiden mutation found to be the commonest cause [6]. Molecular basis of protein ' $\mathrm{C}$ ' deficiency has been studied extensively. The more common genetic defects resulting in deficiency of protein C include Arg 169 Trp, Arg 286 His, Val 297 Met, Asp 359 Asn substitutions, and Lys 150, G 8857 deletions. Screening of these recurrent defects by using restriction enzyme cleavage is a rational method [7].

In conclusion, protein $\mathrm{C}$ deficiency may present as deep vein thrombosis and in any child presenting with features of thrombosis, hereditary risk factors should be ruled out.

Acknowledgments We are thankful to the authority of the Medical College, Kolkata for allowing us to publish this case report. We are also thankful to the parents of the patient for extending their consent to publish this case report.

\section{References}

1. Nair V, Seth AK, Sridhar CM, Chaudhary R, Sharma A, Anand AC (2007) Protein-C deficiency presenting with subacute intestinal obstruction due to mesenteric vein thrombosis. J Assoc Physicians India 55:519-521

2. Scott JP, Montgomery RR (2007) Hemorrhagic and thrombotic diseases. In: Kliegman RM, Behrman RE, Jenson HB, Stanton BF (eds) Nelson text book of pediatric, 18th edn. W.B. Saunders Co, Philadelphia, pp 2060-2065

3. Manco-Johnson MJ, Marlar RA, Jacobson LJ, Hays T, Warady BA (1988) Severe protein C deficiency in newborn infants. J Pediatr 113:359-363

4. Mongale P, Andrew M (2003) Acquired disorders of hemostasis. In: Nathan DG, Oskin SH, Ginsburg D (eds) Hematology of 
infancy and childhood, 6th edn. W.B. Saunders Co, Philadelphia, pp 1631-1668

5. Jeilani M, Ravikumar T, Andal A (2002) Deep vein thrombosis with protein C deficiency. Indian Pediatr 39:689-692

6. Seligsohn U, Lubetsky A (2001) Genetic susceptibility to venous thrombosis. N Engl J Med 344:1222-1231
7. Miyat AT, Sakata T, Yasumuso Y, Okamura T, Katusumi A, Saito $\mathrm{H}$ et al (1998) Genetic analysis of protein 'C' deficiency in 19 Japanese families-five recurrent defects can explain half of the deficiences. Thromb Res 92:181-187 